\title{
A Romanian case study of clothes and accessories upcycling
}

\author{
DOI: $10.35530 / I T .070 .03 .1500$
}

Lucrarea de față urmărește să investigheze practica valorificării și reproiectării. Studiul se bazează pe multiplele organizații implicate în activitățile de reproiectare. Organizațiile selectate pentru studiu sunt situate în partea de nord a României. Interviurile semi-structurate, împreună cu observațiile directe, au fost folosite pentru a colecta informații. Lucrarea oferă informatii practice privind procesul de valorificare. Diferite tipuri de produse reproiectate sunt realizate din deșeuri industriale și de consum, cum ar fi îmbrăcămintea reproiectată, accesoriile pentru femei, gențile, poșetele pentru femei și articolele de papetărie de birou. Valorificarea este considerată, în general, nefezabilă din punct de vedere economic. Cu toate acestea, acest studiu a găsit rezultate contradictorii. Activitățile de reproiectare bazate pe cerere pot ajuta o organizație să obțină profit. Două dintre cele trei organizații selectate sunt capabile să se autosusțină. Una dintre organizații este recent intrată pe piețele românești de îmbrăcăminte și este capabilă să concureze cu jucătorii existenți. Acest studiu ar putea fi văzut ca una dintre primele încercări de a explora empiric practica valorificării textilelor și a accesoriilor în Europa de Est. Constatările din studiul de caz actual pot oferi mai multe informații utile pentru alte companii similare pentru a face activitățile de reproiectare profitabile.

Cuvinte-cheie: valorificare, reproiectare, îmbrăcăminte, piele, accesorii

\section{A Romanian case study of clothes and accessories upcycling}

The present paper aims to investigate the practice of upcycling and redesign. The study draws on the multiple organizations involved in the redesigning activities. The organizations selected for the study are located in the northern part of Romania. Semi-structured interviews along with direct observations were used to collect information. The paper provides practical insights to upcycling process. Various kinds of redesigned products are made out of consumer and industrial wastes such as redesigned clothes, accessories for ladies, handbags, ladies purses and office stationery. Upcycling is generally considered as economically non-feasible. However, this study has found contradictory results. The demand-based redesign activities can help an organization to earn a profit. Two out of three selected organizations are able to self-sustain. One of the organizations is newly entered into the Romanian used clothing markets and ables to compete with existing players. This study could be seen as one of the early attempts to empirically explore the practice of textile and accessories upcycling practice in Eastern Europe. The findings from the current case study can provide several useful insights for other similar companies to make redesign activities profitable.

Keywords: upcycling, redesign, clothes, leather, accessories

\section{INTRODUCTION}

"Upcycling" is an improved and viable way to reuse, in which a product can be used after significant modification [1]. In the present situation, used clothes are reused only for their basic functions as well as for several inferior purposes. In case of inferior usage, the products are not used to its full capacity. Therefore up-cycling can be considered as of the best alternatives over direct reuse and recycling. This is mainly because products are used for the improved purpose, hence higher values can be derived from the existing resources [1]. One successful attempt has been done to maximize the use of resources by firm 'aWEARness'. The company has developed polymer fibres which are long-lasting. Accessibility Based Business Model is developed for the sale of the products. In this business model, the customers do not own the product and ownership lies with the company. The user avails service of the product and then returns back to the company. The company redesign/up-cycle or recycles the product according to the condition [2]. Recycle may be considered as the most conventional process to close the loop. In this process, the raw material is recovered after processing for its properties or characteristics. For example, fire retardant non-woven material recovered can be used in a mattress spring cover [3]. Recycling process can be divided into up-cycling and down-cycling. In up-cycling, value/quality of the product is improved by making a superior product. In down-cycling, an inferior product is made out of raw material. Beside this, reuse of clothes may significantly contribute in reducing the environmental hazard due to the restricted entry of new clothes in the value chain [4-5]. Reverse logistics of clothes for reuse purpose can save energy by $97-98 \%$ in comparison to manufacture same clothes from fibers [6]. The figures illustrate that asup-cycling is better than down-cycling. 
Redesign or upcycling is a way to improve the chance of reuse. Reuse plays a pivotal role to control the environmental degradation by saving natural resources for the future use and reducing pollution. The process of redesigning mainly consists of three steps i.e. ideation, reconstruction and fitting [7]. There are several factors such as material durability, deconstruction efforts and price of redesigned products that can influence the process of redesign. Durable clothing products such as denim jeans are most preferred items for redesign [8]. Paras, Ekwall have found that in the absence of redesign mechanism, even good condition products are incinerated. Incineration and upcycling are two different corners for a product in the term of its use [9]. The upcycling process is economically less feasible due to high labour cost in Western Europe. The current case study can be considered as an instrument to understand how to make redesign process profitable. In the next sections, the methodology will be presented followed by discussion and conclusion.

\section{METHODOLOGY}

An explorative study was conducted to identify the existing practices of up-cycling. Multiple sites were studied which enhanced the robustness of the study [10]. We have chosen the organizations located in lasi, Romania. The data was collected with the help of semi-structured interviews with the founder and senior manager of the organization. The collected data were analysed using a thematic approach. For the present study, three organizations were selected. These are referred as $A, B$, and $C$ to maintain secrecy. $A$ and $C$ are independent social organizations while $B$ is associated to an international charity organization. Table 1 summarises the details of the methodology adopted:

In total, seven interviews were taken at interviewee's office location. The interviews were kept short which lasts for about an hour. These were conducted within a span of one year and six month period i.e., from April 2016 to September 2017. The interviews were conducted with open-ended questions; therefore a protocol has been set to increase the reliability of the information. Different documents along with direct observation technique also helped to get useful infor- mation. NVivo 10 was used to analyse the interviews and other collected information. Interviews transcripts were systematically analysed to find out themes, ideas, patterns, concepts to test deductive framework. Information pertaining to each of the companies was first analyzed individually. Based on the responses, the questionnaires were redefined before moving to the field. During analysis, each of the interviews was compared to previous one to find new formation [11]. Hence, there was a constant backward and forward movement to find new empirical patterns from the case study. On the basis of cross-case analysis, the theoretical saturation was achieved and a model for redesign or upcycling practice is proposed based on the insights [12].

\section{FINDINGS}

This section will provide a practical instance to upcycling practice. Qualitative insights were gained by understanding and analysing the status quo of upcycling practice at three organizations. The organizations chosen for the current case study are specialised in different kind of products, for example, Case A (clothes and accessories), Case B (clothes and leather accessories) and Case C (accessories and stationeries).

\section{Case A: a case of clothes and accessories up-cycling}

Organization A is a Romanian based redesign organization located in the northern part of the country. The organization $A$ is under the umbrella of a 7-yearold social organization that aims to protect the environment. The organization vision is to promote circular economy by minimisation of waste through collection and conversion of discarded textiles to a usable product. The positive impact on the environment is created by redefining clothes, extending the lifespan of textile and creation of new products. The customised products are created by using textiles collected from local people in the bins, along with workshop and factory leftovers. The figure 1 depicts a few illustrations of redesigned clothes and accessories at organization $A$.

The organization $A$ is found to be one of most the successful and economically sustainable organization.

\begin{tabular}{|c|c|c|c|}
\hline \multicolumn{4}{|c|}{ METHODOLOGY USED FOR THE CASE STUDY } \\
\hline Case & $\begin{array}{l}\text { Number of visits } \\
\text { (Direct observation) }\end{array}$ & $\begin{array}{c}\text { Interviews } \\
\text { (Individual face to face) }\end{array}$ & Documents \\
\hline \multirow{3}{*}{ A } & \multirow{3}{*}{06} & Founder & \multirow{3}{*}{ Patterns, work plan, products design etc. } \\
\hline & & Manager & \\
\hline & & Designer & \\
\hline \multirow{3}{*}{ B } & \multirow{3}{*}{$\begin{array}{l}02 \text { (1 visit to the factory at } \\
\text { Ploesti and } 1 \text { visit to } \\
\text { redesign workshop at lasi) }\end{array}$} & Country manager & \multirow{3}{*}{$\begin{array}{l}\text { Inventory records, production planning charts, } \\
\text { products design etc. }\end{array}$} \\
\hline & & Factory manager & \\
\hline & & Redesign manager & \\
\hline C & 01 & Founder & Stationary and accessories pattern, product design etc. \\
\hline
\end{tabular}




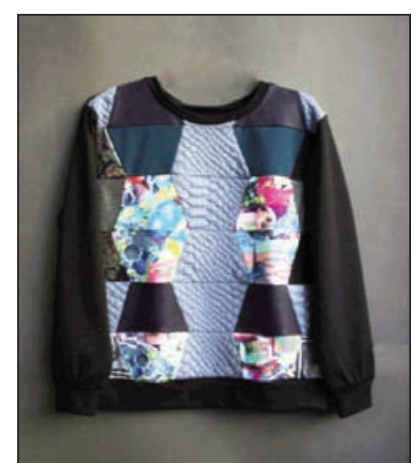

Sweatshirts

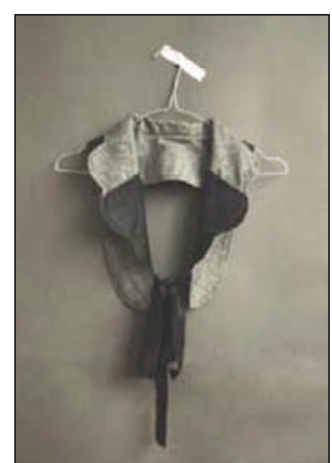

Accessories

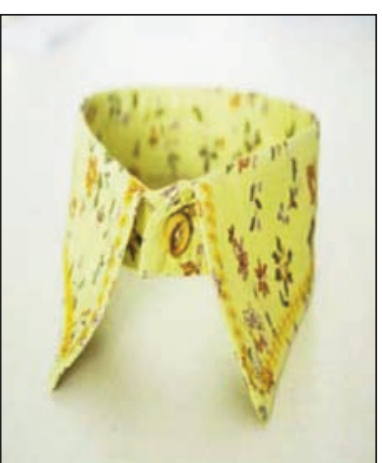

Accessories

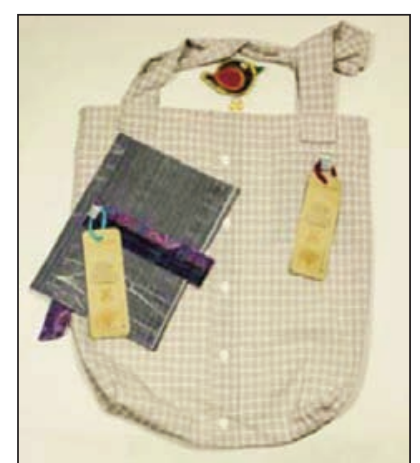

Bag and pouch

Fig. 1. Up-cycled products of organization C (Source: Organization social media websites)

There are five full-time employees involved in the redesign process. The organization works like any other professional organization. The organization participates in different kinds of street festivals to showcase and sell up-cycled products. In order to create awareness about redesign and reuse of textile-based products the organizations A also organise design workshops at regular intervals. The organization has installed 1-2 collection bins near some private shops even though there is no provision of textile collection bins by the municipality. The designers, managers and founder of the organization $A$ keep themselves updated about the latest redesign trends and policies. Recently organization A has collaborated with the Shop of Organization B to get unsold jeans for the redesigning purpose. The organization A has also tied up with the solid waste collector to collect unused and waste textile for the recycling (mainly mechanical).

\section{Case B: a case of clothes and leather accessories up-cycling}

Organization B is a sister company of multinational charity organization. The head office of the company is located in the Bucharest and warehouse is in Ploesti. The organization has two redesign workshops, one is located in the Ploesti and other is located in lasi. The main goal of the organization is to improve the employability and life of Roma people. Various charities and social welfare projects are undertaken to achieve this goal. The finance for the project is earned by the organization from the sale of second hand clothes. Redesign clothes and accessories are exported back to Norway for sales. Some of the up-cycled products from organization $B$ are shown in the below figure 2 .

Organization B is mainly entered into Romanian markets for providing job and training for the Roma (Gypsies), disabled and drug addicted people. The main work of organization B is to import used clothes from Norway and distribute it to the company owned shops after sorting. However, the organization has small facilities for up-cycling clothes for the training purpose. The up-cycling of leather is done at the professional level in the organization B. The leather jackets, trousers and other clothing material found during

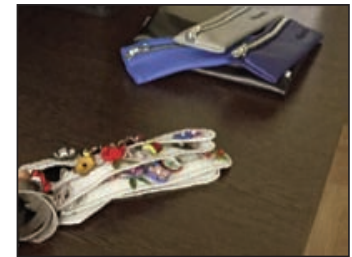

Ladies wallet and bracelets

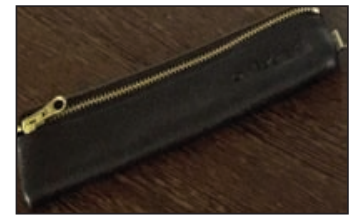

Pencil pouch

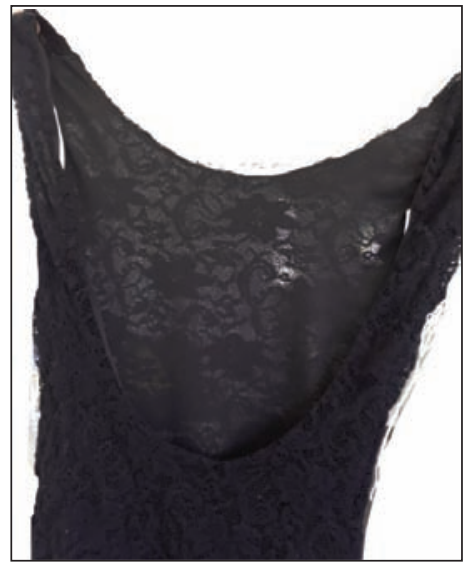

Redesigned dress
Fig. 2. Up-cycled products of organization C

sorting processes are handed over to the redesign team. The redesign team extracted and cut the useful part with the help of cutting machines. Besides this, the redesign team also receive industrial leftover and waste from shoes making companies. Useful leather parts are extracted in the rectangular from the waste and used for making pencil pouch, ladies' wallets, gents' wallets and bracelets. Most of these products are exported to Norway for sale. Some time organization $B$ also receives a unique order like making a net bag to clean football players' clothes in the washing machines.

\section{Case C: a case of accessories and stationeries up-cycling}

This is also a Romania based redesign organization registered as a social organization. Organization C has started its operations in the year 2012 in lasi, a city in the northern part of Romania. The founder of the organization got inspiration from the redesigning/up-cycling, while she was on an internship in an Indian charitable organization. Based on the inspiration, the founder of the organization has started this organization to completely give new shape to the existing waste or discarded materials. The aim of the organization is to convert useless and discarded items into valuable products. Street banners, scrapped fabrics and old trucks covered into bags, wallets, paper folders and others accessories and 


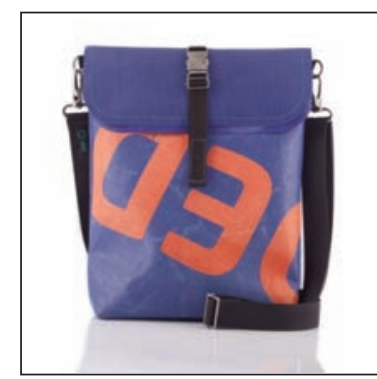

Bag

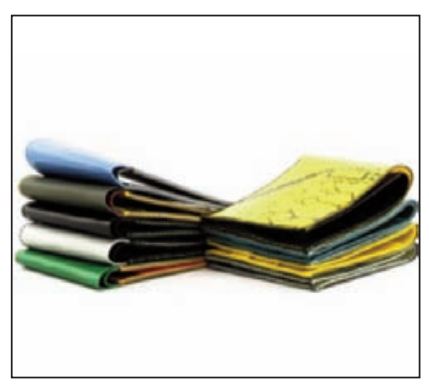

Wallets

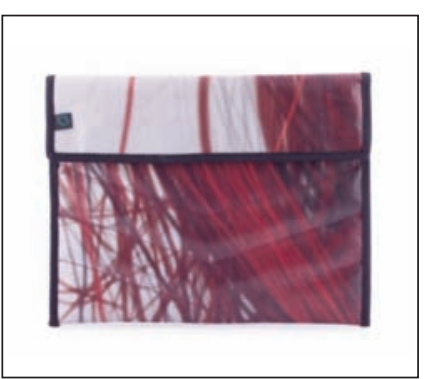

Folders

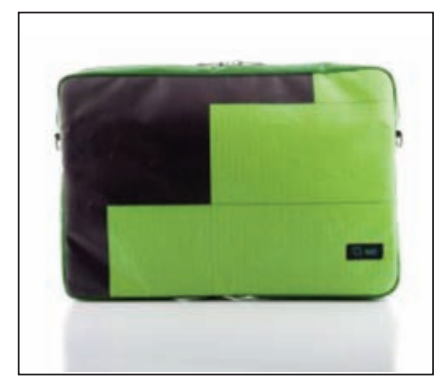

Laptop pouch

Fig. 3. Up-cycled products of organization C (Source: organization website)

stationeries items. Organization $\mathrm{C}$ has contracted with advertising and logistics companies to receive discarded banners and truck covers. Figure 3 depicts some the up-cycled products of the organization C. Organization $\mathrm{C}$ has focused on the banner and truck cover based accessories and stationeries. The organization has collaborated with multiple advertising agencies to receive old banners. Most of the advertising companies are located in the capital city of Romania i.e., Bucharest. Hence, the organization C needs to pay transportation cost to get banners and truck covers in lasi. Organization $\mathrm{C}$ has two employees to cut, sew and pack the accessories and orders. There is no shop owned by company and therefore, the company has collaborated with a few shops located in the different cities of Romania. The shop owners receive a fixed amount of commission for display and sale of the products. The organization also use e-commerce platform for the sale of up-cycled products. Besides the retail sales, the organization also receives bulk orders from the company for the events such as conference, training etc. Similar to the organization $\mathrm{A}$, the organization $\mathrm{C}$ also participate in the various street market to show their presence and sale the products.

Table 2 presents the summary of the existing practices of making clothes, accessories, and stationeries

\begin{tabular}{|c|c|c|c|}
\hline \multicolumn{4}{|c|}{ STATUS QUO OF UP-CYCLING PRACTICE IN THE SELECTED ORGANIZATION } \\
\hline & Organization A & Organization B & Organization C \\
\hline Type & Non profit, Individual & Non profit, Multinational & Non profit, Individual \\
\hline $\begin{array}{l}\text { Government } \\
\text { support }\end{array}$ & Received Norwegian grants & $\begin{array}{l}\text { Receiving all financial } \\
\text { support from the } \\
\text { multinational company }\end{array}$ & Winner of European startup prize \\
\hline $\begin{array}{l}\text { Collection } \\
\text { methods }\end{array}$ & $\begin{array}{l}\text { 1. On Call for bulk collection } \\
\text { 2. Direct handover in } \\
\text { shop/warehouse } \\
\text { 3. Factory leftover } \\
\text { 4. Collection bins at a private place } \\
\text { 5. Unsold items collected from a } \\
\text { second-hand clothes store }\end{array}$ & $\begin{array}{l}\text { 1. Donation from Norwegian } \\
\text { organization. } \\
\text { 2. Factory left over } \\
\text { 3. Collection bins (currently } \\
\text { in process of permission) }\end{array}$ & $\begin{array}{l}\text { 1. Direct handover } \\
\text { 2. Agreement with advertising } \\
\text { and transport companies }\end{array}$ \\
\hline $\begin{array}{l}\text { Redesigned } \\
\text { facilities }\end{array}$ & $\begin{array}{l}\text { Equipped with basic machines } \\
\text { required for a redesign, such as: } \\
\text { 1. Sewing machines } \\
\text { 2. Block printing machines } \\
\text { 3. Single head embroidery } \\
\text { machines } \\
\text { 4. Ironing, cutting table }\end{array}$ & $\begin{array}{l}\text { Equipped with modern } \\
\text { facilities required for a } \\
\text { leather redesign, such as: } \\
\text { 1. Sewing machines } \\
\text { 2. Leather cutting machines } \\
\text { 3. Leather pressing } \\
\text { machines }\end{array}$ & $\begin{array}{l}\text { Equipped with basic machines } \\
\text { required for a redesign, such as: } \\
\text { 1. Sewing machines } \\
\text { 2. Cutting tables } \\
\text { Note: Printing operations are } \\
\text { outsourced tothe currently } \\
\text { in-house facility is not available. }\end{array}$ \\
\hline Sale & $\begin{array}{l}\text { 1. Sales in own shop } \\
\text { 2. Online sale through own } \\
\text { e-commerce websites } \\
\text { 3. Products are displayed and sold } \\
\text { in sister organizations cafeteria } \\
\text { 4. On order manufacturing and } \\
\text { sales }\end{array}$ & $\begin{array}{l}\text { 1. Most of the redesigned } \\
\text { accessories are exported } \\
\text { to Norway } \\
\text { 2. Sometimes products are } \\
\text { also displayed in the } \\
\text { organization owned a } \\
\text { second-hand shop }\end{array}$ & $\begin{array}{l}\text { 1. Company-owned e-commerce } \\
\text { websites } \\
\text { 2. Agreement with shops in 3-4 } \\
\text { cities. Organization C } \\
\text { accessories and stationeries } \\
\text { are displayed and sold on a } \\
\text { commission basis. } \\
\text { 3. On order manufacturing and } \\
\text { sales }\end{array}$ \\
\hline
\end{tabular}


out of discarded used products. The interviews indicated that all the three companies have different methods to perform redesign activities. $A$ and $C$ are individual charitable social organizations working independently. While organization B is sister organization of a Norwegian multinational charity organization that are further taking support from their allied organizations to sale up-cycled products. Up-cycling and redesigning activities are not main focus as organization $B$ is a member of a multinational charity organization and has financial support from the parent organization. The main focus of the organization is to engage disabled and alcoholic people whereas for organization A and C, up-cycling is a profession to self-sustain and support day to day activities.

\section{DISCUSSION AND CONCLUSION}

The process of redesign varies from one organization to other organization. Organization A believes in the demand-based redesign. The founder and manager of the organization shared that there is no point in producing anything that cannot be sold. Hence, the organization emphasise on first receiving orders and accordingly producing redesign products for the customers. However, some of the products that have regular demand are also produced based on the expected demand which is estimated based on the experience of the founding members. Organization B remakes new product from industrial and consumer discards based on the requirements of the sister concerned located in Norway. However, some of the products are also reshaped or redesign for the local shops. Overall, organization B performs two kinds of redesign practices, one is demand-based and other is product based. Organization $\mathrm{C}$ is making products from old advertisements banners and truck covers. The discarded materials are transported by the advertising or transport companies to Organization $\mathrm{C}$ and the company is responsible for the payment of the transportation cost. The dirty materials are cleaned and stored for the future use as per demand. Organization $\mathrm{C}$ mostly do redesigning based on the order received from banks, institutes, information technology companies etc. However, organization C also keeps on making some standard products such as bags, pouch, wallets etc. Among all the organizations, the demand based upcycling is found to be a common approach. Demand-based redesign approach found to be highly sustainable because only those items are produced that are required in the market which results in saving the manpower, money and efforts. Organization $A$ redesigns based on the demand of the product. This enables the organization to sustain financially and get fair returns. Advertising through social media is done to create the demand for newly redesigned clothes and accessories. Organization B produces items for the order received from sister organizations from Norway. Organization C works on corporate orders and regular requirements of an online shop and normal shops.

The investigation of upcycling practice revealed that there aredifferent approaches to carry out upcycling practice. An upcycling process consists of ideation, reconstruction and fitting stages. Inferior fabric quality and fast fashion can be considered as main barriers for upcycling. The 'product based redesign' and 'demand-based redesign' are some of the strategies that can boost upcycling. Variations in size, colour and pattern pose another set of problems. Solution to these problems can be achieved through skill enhancement programmes and innovation. Along with a set of skill, the person involved in the redesign process should have the desire and ready to devote time to it. Retaining provenance and narrative increase chance of clothes purchase. Upcycling operation is still at its nascent stage which leads to high cost of operation. Support of government and volunteers can make redesigning process cost-effective and successful. Upcycling has various benefits which include environmental benefits and monetary benefits for the individuals. In future, the current study can be extended by the mathematical formulation of the upcycling and redesigning process by applying different techniques such as genetic algorithm, artificial intelligence and other simulation techniques. A quantitative study such as model development can also provide a good avenue to extend the work. Future scholars can further study the role of price, design and consumer attitude along with the quality of clothing on the value chain. Validation of current finding in different geographical context can provide useful insights.

\section{ACKNOWLEDGEMENT}

This work is conducted at "Gheorghe Asachi" Technical University of lasi, Romania under SMDTexproject. We would like to acknowledge the financial support provided by EU.

\section{BIBLIOGRAPHY}

[1] Cuc, S. and Tripa, S. Redesign and upcycling-a solution for the competitiveness of small and medium-sized enterprises in the clothing industry. In: Industria Textila, 2018. 69(1), pp. 31-36.

[2] Dervojeda, K., Verzijl, D. and Rouwmaat, E. EU-circular-supply-chains..In: Business Innovation Observatory, 2014.

[3] Morley, N.J., Bartlett, C. and McGill, I. Maximising reuse and recycling of UK Clothing and Textiles. A research report completed for the Department for Environment, Food and Rural Affairs. In: Quality, 2009, p. 10.

[4] Farrant, L., Olsen, S.I. and Wangel, A. Environmental benefits from reusing clothes. In: International Journal of Life Cycle Assessment, 2010, 15, pp. 726-736. 
[5] Tipper, M.J., et al. Principles of the recovery and reuse of corporate clothing. In: Proceedings of the ICE - Waste and Resource Management, 2010, 163 (November), p. 165-172.

[6] Woolridge, A.C., et al. Life cycle assessment for reuse/recycling of donated waste textiles compared to use of virgin material: An UK energy saving perspective. In: Resources Conservation and Recycling, 2006, 46(1), pp. 94-103.

[7] Paras, M.K. and Curteza, A. Revisiting upcycling phenomena: a concept in clothing industry. In: Research Journal of Textile and Apparel, 2018, 22(1), pp. 46-58.

[8] Paras, M.K., Pal, R. and Ekwall, D. Systematic literature review to develop a conceptual framework for a reusebased clothing value chain. In: The International Review of Retail, Distribution and Consumer Research, 2017, pp. 1-28.

[9] Paras, M.K., et al. An exploratory study of Swedish Charities to develop a model for the reuse-based clothing value chain. In: Sustainability, 2018, 10(4), p. 1176.

[10] Herriott, R.E. and Firestone, W.A. Multisite qualitative policy research: Optimizing description and generalizability. In: Educational Researcher, 1983, 12(2), pp. 14-19.

[11] Czarniawska, B., Social science research: From field to desk, 2014, SAGE Publications.

[12] Bryman, A. and Bell, E. Business research methods, 2015, Oxford University Press.

\section{Authors:}

\section{MANOJ KUMAR PARAS ${ }^{1,2,3}$ \\ ANTONELA CURTEZA ${ }^{2}$ \\ RUDRAJEET PAL ${ }^{3}$ \\ YAN CHEN ${ }^{1}$ \\ LICHUAN WANG $^{1}$}

${ }^{1}$ College of Textile and Clothing Engineering, Soochow University,

Suzhou 215006, China

2"Gheorghe Asachi” Technical University of lasi,

Bulevardul Profesor Dimitrie Mangeron 67, Iasi, 700050, Romania

${ }^{3}$ Faculty of Textiles, Engineering and Business, University of Borås, Allégatan 1, 50139032 Borås, Sweden

\section{Corresponding author:}

\section{LICHUAN WANG}

e-mail: Lcwang@suda.edu.cn

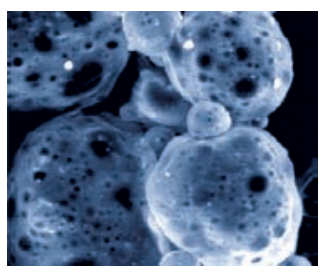

